\title{
60S Ribosomal Protein L13a
}

National Cancer Institute

\section{Source}

National Cancer Institute. 60S Ribosomal Protein L13a. NCI Thesaurus. Code C104763.

60S ribosomal protein L13a (203 aa, $24 \mathrm{kDa}$ ) is encoded by the human RPL13A gene.

This protein plays a role in translation as a structural protein of the $60 \mathrm{~S}$ ribosome subunit. 